\title{
SPOR BILIMLERINDE SOSYAL KÜLTÜREL SERMAYE VE GiRişiMCILIK
}

EDITÖR

Çetin TAN

YAZAR

İsa ÇifTÇi 


\section{(C) Copyright 2020}

Bu kitabın, basım, yayın ve satış hakları Akademisyen Kitabevi A.Ş.'ne aittir. Anılan kuruluşun izni alınmadan kitabın tümü ya da bölümleri mekanik, elektronik, fotokopi, manyetik kağıt ve/veya başka yöntemlerle çoğaltılamaz, basılamaz, dağıtılamaz. Tablo, şekil ve grafikler izin alımmadan, ticari amaçh kullanılamaz. Bu kitap T.C. Kültür Bakanlı̆ı bandrolü ile satılmaktadır.

*Bu Çalışma danışmanlığını Doç. Dr. Çetin TAN’ın yaptığı İsa ÇíFTÇì’ye ait Doktora Tezinden üretilmiştir.

\section{ISBN}

978-625-7275-82-8

\section{Kitap Adı}

Spor Bilimlerinde Sosyal Kültürel Sermaye ve Girişimcilik

\section{Editör}

Çetin TAN

Yazar

İsa ÇİFTÇİ

\section{Yayın Koordinatörü \\ Yasin Dilmen}

Sayfa ve Kapak Tasarımı

Akademisyen Dizgi Ünitesi

\section{Yayıncı Sertifika No}

47518

Baskı ve Cilt

Vadi Matbaacılık

Bisac Code

SPO000000

\section{GENEL DAĞITIM}

\section{Akademisyen Kitabevi A.Ş.}

Halk Sokak 5 / A

Yenişehir / Ankara

Tel: o312 4311633

siparis@akademisyen.com

\section{www . akade misyen.com}




\section{IÇiNDEKILER}

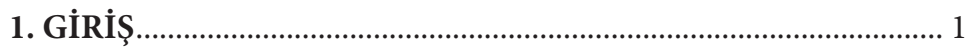

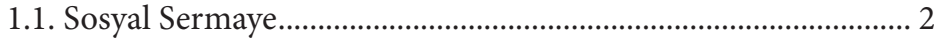

1.1.1. Sosyal Sermayenin Tarihsel Gelişimi ......................................... 3

1.1.2. Sosyal Sermaye Teorisyenleri .................................................... 4

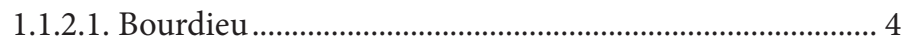

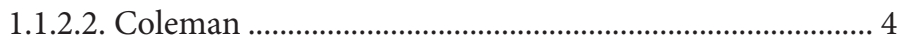

1.1.2.3. Robert Putnam ................................................................... 5

1.1.2.4. Francis Fukuyama ................................................................... 5

1.1.3. Sosyal Sermayenin Belirleyici Faktörleri ................................. 6

1.1.4. Sosyal Sermaye Türleri ............................................................... 6

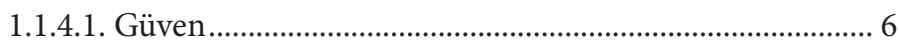

1.1.4.2. Normlar ............................................................................ 7

1.1.4.3. Sosyal Ağlar....................................................................... 8

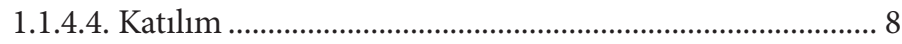

1.1.5. Sosyal Sermaye ve Eğitim ....................................................... 8

1.1.6. Sosyal Sermayenin Girişimcilik Açısından Önemi.................. 9

1.1.7. Sosyal Sermayenin Kaynakları .................................................. 10

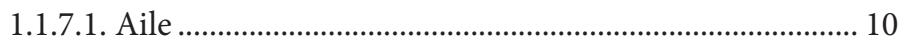

1.1.7.2. Sivil Toplum Kuruluşları .................................................... 10

1.1.7.3. Devlet.......................................................................... 10

1.2. Kültürel Sermaye ....................................................................... 11

1.2.1. Kültürel Sermaye Türleri........................................................ 12

1.2.1.1. Bedenselleşmiş (İçşelleşmiş) Kültürel Sermaye.............. 12

1.2.1.2. Nesneleşmiş Kültürel Sermaye ........................................... 12

1.2.1.3. Kurumsallaşmış Kültürel Sermaye ..................................... 12 
1.2.2. Kültürel Sermayenin Boyutları ............................................ 13

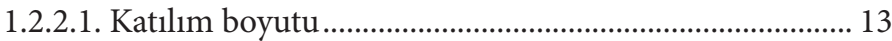

1.2.2.2. Entelektüel Birikim Boyutu............................................ 13

1.2.2.3. Kültürel Potansiyel Boyutu................................................. 13

1.2.2.4. Kültürel Bilinç Boyutu ........................................................ 13

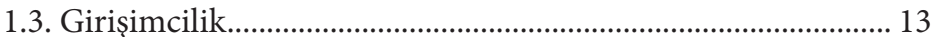

1.3.1. Girişimciliğin Önemi ........................................................... 14

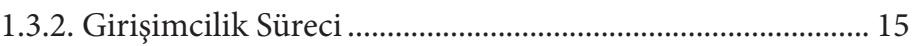

1.3.2.1. Girişimciliğe Yönelik Heves ve Motivasyona Sahip

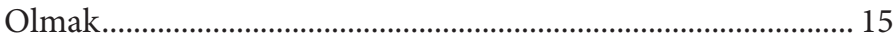

1.3.2.2. İş Planı Hazırlama ............................................................... 15

1.3.2.3. İş Geliştirme ve Büyütme ................................................ 15

1.3.3 Girişimcilik Eğilimini Etkileyen Etmenler .......................... 15

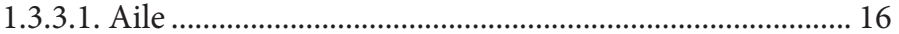

1.3.3.2. Yaş ve Cinsiyet ................................................................... 16

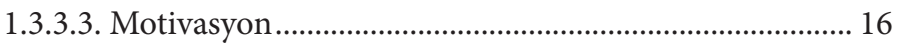

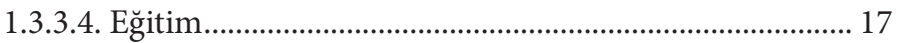

1.3.3.5. Risk Alma Eğilimi ............................................................ 17

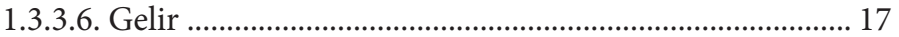

1.3.4. Girișimcinin Özellikleri ................................................................ 18

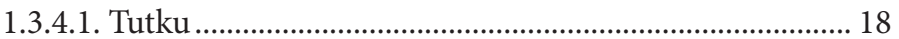

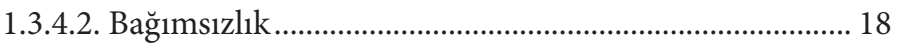

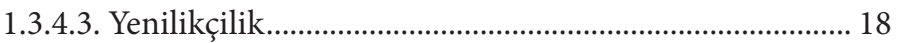

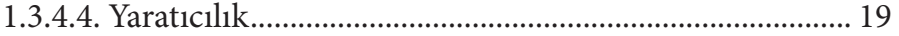

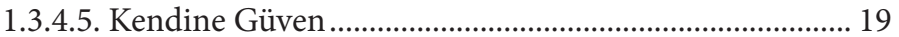

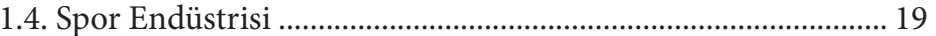

1.4.1. Sporun Diğer Endüstrilerle Olan İlişkisi ............................. 20

1.4.2. Spor Endüstrisinin Büyüme ve Gelişmesinin Sebepleri .... 21

1.4.2.1. Yeni, Farklı Spor, Fitness ve Rekreasyon Etkinliklerinin Sayısal Artışı ve Gelişimi .................................................................. 21

1.4.2.2. Kitle İletişim Araçlarındaki Artış..................................... 21 
1.4.2.3. Bireylerin Serbest Zamanlarının Artışı 21

1.4.2.4. Çeşitli Pazar Bölümlerinde Spor Ürünlerinin Artması ve Bu Ürünlerle İlgili Teknolojik Gelişmeler 21

1.5. Spor Pazarlamas1.............................................................................. 22

1.6. Spor ve Girişimcilik.................................................................. 22

1.6.1. Sporda Girişimciliğin Önemi ............................................... 22

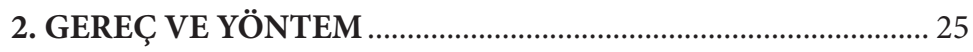

2.1. Araştırmanın Modeli ................................................................... 25

2.2. Araştırmanın Hipotezleri ............................................................ 25

2.3. Araştırmanın Amacı ve Önemi .................................................. 26

2.4. Araştırmanın Sinırlılıkları........................................................... 26

2.5. Araştırmanın Varsayımları......................................................... 26

2.6. Evren ve Örneklem.................................................................... 27

2.7. Veri Toplama Araçları.............................................................. 28

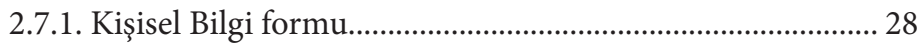

2.7.2. Bireysel Girişimcilik Alg1 Ölçeği........................................... 28

2.7.3. Sosyal ve Kültürel Sermaye Özellikleri Ölçeği ..................... 29

2.8. Verilerin Analizi .......................................................................... 30

2.9. Araştırmada Kullanılan Ölçeklere Yönelik Geçerlik ve Güvenirlik Analizleri ................................................................................... 30

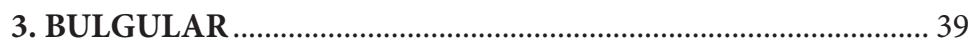

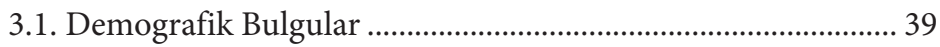

3.2. Bireysel Girişimcilik Algısı Ölçeği ve Sosyal ve Kültürel Sermaye Özellikleri Ölçeğine Katılma Düzeyleri. 43

3.3. Öğrencilerin Demografik Özelliklerine Göre Bireysel Girişimcilik Algısı Analiz Sonuçları ................................................................ 45

3.4. Öğrencilerin Demografik Özelliklerine Göre Sosyal ve Kültürel Sermaye Özellikleri Ölçeği Analiz Sonuçları 84

3.5. Bireysel Girişimcilik Algısı Ölçeği ile Sosyal ve Kültürel Sermaye 
Özellikleri Ölçeği Alt Boyutları Arasındaki Korelasyon Analizi Sonuçları.. 143

3.6. Bireysel Girişimcilik Algısı Ölçeği ile Sosyal Sermaye ve Kültürel Sermaye Özellikleri Ölçeği Arasındaki Regresyon Analizi Sonuçları 154

4. TARTIŞMA VE SONUÇ................................................................. 157

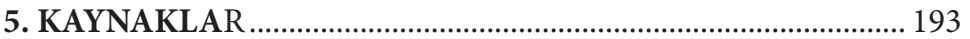




\section{KAYNAKLAR}

1. Türkoğlu T, Tetik S, Açıkgöz A. Meslek Yüksekokulu Öğrencilerinin Sosyo-Demografik Özellikleri İle Girişimci Kişilik Özellikleri Arasındaki İlişkinin Araştırılması. Journal Of Yasar University, 2017; 12(45): 1-13.

2. Öztürk HK. Almanya’da Girişimcilik - Eğitimi ve Okullarda Uygulamalı Örnekleri. The Journal Of International Scientific Researches, 2019; 4(2): 222-233.

3. Özman C. Sporda Girişimcilik Üzerine Bir Araştırma. Saarbrücken: Türkiye Alim Kitapları, 2016.

4. Akyazı TE. Girişimcilik Sürecinde Sosyal Sermaye ve Sosyal Ağlar İle İç Girișimcilik Arasındaki İlișki Üzerine Bir Araştırma. Yüksek Lisans Tezi, Aksaray: Aksaray Üniversitesi, Sosyal Bilimleri Enstitüsü, İşletme Anabilim Dal, 2014.

5. Aksan G. Yoksulluk ve Dayanışma Ağları. Konya: Çizgi Kitabevi, 2015.

6. Karadal H, Akyazı TE. Sosyal Sermaye ve Girişimcilik. Karadal H (Ed.), Girişimcilik, 75-93, Beta Yayınevi, 2013.

7. Torshabi A, Taboli H. Study Of The Relationship Between Emotional İntelligence And Social Capital With Regard To The Trust Role Of The Mediator İn Between The Staff Of The Department Of Roads And Urban Development İn The City Of Zahedan. International Journal Of Humanities And Cultural Studies, Special İssue, 2016; 1758-1767.

8. Luthans F, Youssef CM. Emerging Positive Organizational Behavior. Journal Of Management, 2007; 33(3): 321-349.

9. María J, Vidales B, Chalezquer CS. Connected Teens: Measuring The Impact Of Mobile Phones On Social Relationships Through Social Capital. Comunicar, 2017; 25(5)3: 20.

10. Fredrica N. - Anna KF. Healthy Ageing: Focus On Social Capital. Social Capital As A Health Resource İn Later Life: The Relevance Of Context, Ed. Fredrica Nyqvist - Anna K. Forsman, International Perspectives On Aging, Springer Netherlands, 2015.

11. James F. Social Capital: A Conceptual History. Political Theory, 2004; 32(1):7.

12. Hans W. Social Capital İn The Knowledge Economy: Theory And Empirics. New York: Springer, 2006.

13. Gerni M. Sosyal Sermaye ve Örgütsel Boyutu. İstanbul: Beta Yayınları, 2013.

14. Bourdieu P. The Forms Of Capital. Handbook Of Theory And Research For The Sociology Education. (J. Richardson, Dü.) New York: Greenwood Press, 1986. 
15. Alacahan O, Duman B. Güven ve Sivil Bağlllık Boyutuyla Sosyal Sermaye ve Mezhep: Kahramanmaraş Örneği. Elektronik Sosyal Bilimler Dergisi, 2011; 10(36): 108-131.

16. Coleman JS. Social Capital İn The Creation Of Human Capital. The American Journal Of Sociology, 1988; 94: 95-120.

17. Devamoğlu S. Sosyal Sermaye Kuramı Açısından Türkiyede Demokrasi Kültürü Üzerine Bir Değerlendirme. Yüksek Lisans Tezi, Denizli: Pamukkale Üniversitesi, Sosyal Bilimler Enstitüsü, Kamu Yönetimi Anabilim Dalı, 2008.

18. Özuğurlu A. Sosyal Sermaye: Kamunun Trajedisi ya da Emeğin Sömürgeleştirilmesinde Yeni Bir Eşik. Akdeniz İktisadi ve İdari Bilimler Fakültesi Dergisi, 2006; 12: 188-213.

19. Field J. Sosyal Sermaye. Bilgen B, Şen B. (Çeviren). 2. Baskı, İstanbul: İstanbul Bilgi Universitesi Yayınları, 2008.

20. Tokas S. Education And Social Capital. Learning Community, 2016; 7(3): 257- 265.

21. Fukuyama F. Güven: Sosyal Erdemler ve Refahın Yaratılması. Buğdaycı A(Çeviren). İstanbul: İş Bankası, 2005.

22. Halpern D. Social Capital. Cambridge: Polity Press, 2005.

23. Olate R. Local İnstitutions, Social Capital And Capabilities: Challenges For Development And Social İntervention İn Latin America, 2003.

24. Iyer S, Kitson M, Toh B. Social Capital, Economic Growth And Regional Development. Regional Studies, 2005; 39(8): 1015-1040.

25. Billett P. Indicators Of Youth Social Capital The Case For Not Using Adult Indicators In The Measurement Of Youth Social Capital. Youth Studies Australia, 2012; 31(2): 9-15.

26. Can İ. Güven Araştırmaları Güvenilir mi? Sosyal Güven Araştırmalarının Yöntemine İlişkin Eleştirel Bir Yaklaşım. Manas Sosyal Araştırmalar Dergisi, 2018; 7(2): 481-497.

27. Türk Dil Kurumu. Tarihinde Http://Www.Tdk.Gov.Tr/ Adresinden 16 Aralık 2019 tarihinde erişim sağlandı.

28. Yağmur A. Sosyal Sermayenin Bölgesel Kalkınmaya Etkisi. Selçuk Üniversitesi Sosyal ve Teknik Araştırmalar Dergisi, 2017; 13: 111-124.

29. Fukuyama F. Sosyal Sermaye ve Sivil Toplum. Şahin M, Ünal AZ (Çeviren). Sosyal Sermaye Kuram Uygulama Eleştiri, İstanbul: Değişim Yayınları, 1999.

30. Eroğlu E. Geçmişten Günümüze Sosyal Normlar. Akademik Bakış Dergisi, 2015; (50): 299-308.

31. Namalır MM. Okul Yöneticileri ve Öğretmenlere Göre Sosyal Sermayenin Okullarda Kullanma Düzeyi. Yüksek Lisans Tezi, Ankara: Gazi Üniversitesi, 2015.

32. Coleman JS. Foundations Of Social Theory. The Belknap Press Of Harvard University Press. Cambridge, Ma. 1990. 
33. Uçar ME. Üniversite Öğrencileri ve Ünivesiteden Mezun Olan Bireylerin Sosyal Sermaye Düzeylerinin Benlik Biçimleri ve Çeşitli Değişkenler Açısindan İncelenmesi. Doktora Tezi, Ankara: Ankara Üniversitesi, 2010.

34. Günkör C, Özdemir MÇ. Sosyal Sermaye ve Eğitim İlişkisi. Türk Eğitim Bilimleri Dergisi, 2017; 15(1): 70-90.

35. Olimid AP. Civic Engagement And Citizen Participation İn Local Governance: Innovations İn Civil Society Research. Revista De Stiinte Politice, 2014; 44: 73-84.

36. Baum FE, Ziersch AM. "Social Capital", Journal Of Epidemiology And Community Health (1979-) 57/5, 2003: 320.

37. Goss KA. Civil Society And Civic Engagement: Towards A Multi-Level Theory Of Policy Feedbacks. Journal Of Civil Society, 2010; 6(2): 119-143.

38. Alemdar M. Ortaöğretim Öğrencilerinin Duygusal Okuryazarlık Beceri Düzeylerinin Belirlenmesi. Yüksek Lisans Tezi, Eskişehir: Eskişehir Osmangazi Üniversitesi, Eğitim Bilimleri Enstitüsü, Eğitim Bilimleri Anabilim Dalı, 2014.

39. Uğuz HE. Sosyal Sermaye. Ankara: Orion, 2010.

40. Tüysüz N. Sosyal Sermayenin Ekonomik Gelişme Açısından Önemi ve Sosyal Sermaye Endeksinin Hesaplanması. Kalkınma Bakanlığı, Yayın No: 2827. 2011.

41. Rogošić S, Baranović B. Social capital and educational achievements: Coleman vs. Bourdieu. Center for Educational Policy Studies Journal, 2016; 6(2): 81-100.

42. Karayılan D. Kuruluş Aşamasında Girişimcilik Türlerinde Sermaye Önceliklerinin Belirlenmesine Yönelik Bir Çalışma: Gaziantep İli Örneği. Doktora Tezi, Gaziantep: Hasan Kalyoncu Üniversitesi Sosyal Bilimler Enstitüsü, İşletme Anabilim Dalı, 2019.

43. Şavkar E. Sosyal Sermayenin Unsurları ve Ekonomik Kalkınmayla İlişkisi. Yüksek Lisans Tezi, Afyon: Afyon Kocatepe Üniversitesi, 2011.

44. Karagül M, Masca M. Sosyal Sermaye Üzerine Bir İnceleme. Ekonomik ve Sosyal Araştırmalar Dergisi, 2005; 1: 37-52.

45. Kaya Y. Sosyal Sermaye Düzeyinin Belirlenmesi ve Sosyal Sermaye Düzeyini Etkileyen Faktörlerin Analizi: Gönüllü Teşekküller Bağlamında Kayseri Örneği. Yüksek Lisans Tezi, Kütahya: Dumlupınar Üniversitesi, 2011.

46. Türk Dil Kurumu. (Www.Tdk.Gov.Tr). 25.07.2018.

47. Throsby D. Cultural Capital. Journal Of Cultural Economics, 1999; 23: 3-12.

48. Ekşioğlu ŞZ. Kültürel Sermaye ve Ekonomik Kalkınma Arasındaki İlişkinin Girdi Çıktı Analizi ve Fayda Maliyet Analizi Yöntemleri İle Türkiye İçin Değerlendirilmesi. Doktora Tezi, İstanbul: Kadir Has Üniversitesi, Sosyal Bilimler Enstitüsü, 2012.

49. Andersen, IG, Jæger MM. Cultural Capital İn Context:Heterogeneous Returns To Cultural Capital Across Schooling Environments. The Danish 
National Centre For Social Research, Copenhagen; Department Of Sociology, University Of Copenhagen, Denmark, 2013.

50. Avc1 YE. Öğretmenlerin Kültürel Sermaye Yeterliklerinin İncelenmesi. Doktora Tezi, Gaziantep: Gaziantep Üniversitesi, Eğitim Bilimleri Enstitüsü, 2015.

51. Saraceno C. Do We Need Capital Accounts For Culture? Http://Www. Carloalberto.Org/Assets/Working-Papers/No.367. 2014, Pdf, Erişim Tarihi: 17.05.2016.

52. Jourdain A, Naulin S. Pierre Bourdieu'nun Kuramı ve Sosyolojik Kullanımları. Elitez Ö (Çeviren). İstanbul: İletişim Yayıncılık, 2016.

53. Özdemir AA. Sosyal Ağ Özellikleri Bakış Açısıyla Sosyal Sermaye ve Bilgi Yaratma İlişkisi: Akademisyenler Üzerinde Bir Uygulama. Doktora Tezi, Eskişehir: Anadolu Üniversitesi, Sosyal Bilimler Enstitüsü, 2007.

54. Bayram GN. Girişmcilik Eğitiminin Girişimcilik Eğilimi Üzerine Etkisinin İncelenmesine Yönelik Bir Araştırma. Yüksek Lisans Tezi, İstanbul: Hassn Kalyoncu Üniversitesi, Sosyal Bilimler Enstitüsü, İşletme Anabilim Dali, 2014.

55. Hancıoğlu Y, Tekin E. Genç Girişimci Adaylarının Girişimcilik Eğilimlerinin Değerlendirilmesi: Uygulamalı Girișimcilik Kampüsü Üzerine Bir Araştırma. Çankırı Karatekin Üniversitesi İktisadi ve İdari Bilimler Fakültesi Dergisi, 2018; 8(1); 213-246.

56. Özkan Ş, Emsen ÖS, Gündoğdu F, Aksu H. Türkiye’de Girişimcilik ve Belirleyicileri: Marmara ve Doğu Anadolu Bölgesi Üzerine Bir Uygulama. Ankara Üniversitesi Sbf Dergisi, 2003; 54(4): 145-172.

57. Ekici E. Üniversite Öğrencilerinin Girişimcilik Eğilimini Belirlemede Planlanmış Davranışlar Teorisi ve Girişimcilik Eğitiminin Rolü. Yüksek Lisans Tezi, Adana: Çukurova Üniversitesi, Sosyal Bilimler Enstitüsü, Yönetim ve Organizasyon Anabilim Dalı, 2016.

58. Balaban Ö, Özdemir Y. Girişimcilik Eğitiminin Girişimcilik Eğilimi Üzerindeki Etkisi: Sakarya Üniversitesi İ.İ.B.F. Örneği, Girişimcilik ve Kalkınma Dergisi, 2008; 32: 133-148.

59. Taş HY, Bilen M. Hak-İş Uluslararası Emek ve Toplum Dergisi, 2014; 3(6).

60. Borgese A. Standarts in Sports Entrepreneurship Education, (Doktora Tezi) United States Sports Academy, Brooklyn, New York, USA, 2007.

61. Marangoz M. Girişimcilik. İstanbul: Beta Basım Yayım, 2012.

62. Yıldırım H. Girişimcilik Ateşi ve İş Melekleri Temel Kavramlar ve Ateşte Çiçek Açtıran İş Melekleri. İstanbul: Değişim Yayınları, 2008.

63. İraz R. Yaratıcılık ve Yenilik Bağlamında Girişimcilik ve Kobiler. Konya: Çizgi Kitabevi, 2005.

64. Arıkan S. Girişimcilik Temel Kavramlar ve Bazı Güncel Konular. Ankara: Siyasal Kitabevi, 2002. 
65. Cansız M. Türkiye’nin Yenilikçi Girişimcileri Teknoloji Geliştirme Bölgeleri Örneği. T.C. Kalkınma Bakanlığı, Sosyal Sektörler ve Koordinasyon Genel Müdürlüğü (Temmuz, Yayın No: 2850), 2013.

66. Yatkın A, Ölmez M. Girişimcilik ve Girişimcinin Tamamlayıcı Unsurları. E-Journal Of New World Sciences Academy, 2011; 6(2): 187-201.

67. Müftüoğlu T, Durukan T. Girişimcilik ve Kobiler. Ankara: Gazi Kitabevi, 2004.

68. Henry C, Hill F, Leitch C. Entrepreneurship Education And Training. England: Ashgate Publishing Limited, 2003.

69. Şahin E. Kadın Girişimcilik ve Konya İlinde Kadın Girişimcilik Profili Üzerine Bir Uygulama. Yüksek Lisans Tezi, Konya: Selçuk Üniversitesi, Sosyal Bilimler Enstitüsü, İşletme Anabilim Dalı, 2006.

70. Bedük A. Türkiye’de Çalışan Kadın ve Kadın Girişimciliği. Elektronik Sosyal Bilimler Dergisi, 2005; 3(12): 106-117.

71. Avşar M. Yükseköğretimde Öğrencilerin Girişimcilik Eğilimlerinin Araştırılması, Çukurova Üniversitesinde Bir Uygulama. Yüksek Lisans Tezi, Adana: Çukurova Üniversitesi, Sosyal Bilimler Enstitüsü, İşletme Ana Bilim Dali, 2007.

72. Aydın E, Öner G. Sosyal Bilgiler ve Sınıf Öğretmeni Adaylarının Girişimcilik Düzeylerinin İncelenmesi. Ahi Evran Üniversitesi Kırşehir Eğitim Fakültesi Dergisi (Kefad), 2016; 17(3): 497-515.

73. Linan F, Moriano JA, Zarnowska A. Stimulating Entrepreneurial Intentions Through Education. In. J. A. M., Leon, M., Gorgievski Ve M., Lukes (Eds.), Teaching Psychology Of Entrepreneurship, Madrid: Universidad Nacional De Educacion A Distanci, 2008.

74. Altuntaş G, Dönmez D. Girişimcilik ve Yönetimi Örgütsel Performans İlişkisi: Çanakkale Bölgesinde Faaliyet Gösteren Otel İşletmelerinde Bir Araştırma. İstanbul Üniversitesi İşletme Fakültesi Dergisi, 2010; 39(1): 50-74.

75. Henry C, Hill F, Leitch C. Entrepreneurship Education And Training. England: Ashgate Publishing Limited, 2003.

76. Cardon MS, Zıetsma C, Saparito P, Matherne BP, Davis C. A Tale Of Passion: New Insights İnto Entrepreneurship From A Parenthood Metaphor. Journal Of Business Venturing, 2005; 20: 23-45.

77. Alvarez C, Urbano D. Cultural-Cognitive Dimension And Entrepreneurial Activity: A Cross-Country Study, Revista De Estudios Sociales, 2012; 44: 146-157.

78. Demiroğlu Y. Firma Davranışı Olarak Girişimcilik. Yüksek Lisans Tezi, İzmir: Dokuz Eylül Üniversitesi Sosyal Bilimler Enstitüsü, 2007.

79. https://aofgirisimcilik.wordpress.com/ (28.03.2016).

80. Hallak R, Brown G, Lindsay JN. The Place İdentity E Performance Relationship Among Tourism Entrepreneurs: A Structural Equation Modelling Analysis. Tourism Management, 2011; 33(1): 143-154. 
81. Pedersen PM, Thibault L. Contemporary Sport Management (5th Edition). Champaign: Human Kinetics, 2014.

82. Thompson R. What İs Sportainment. 2014.

83. Altunbaş H. Spor Pazarlaması ve Pazarlama İletişiminde Spor. Selçuk İletișim, 2007.

84. Li M, Hofacre S, Mahony D. Economics Of Sport. Morgantown: Fitness Information Technology, 2001.

85. Argan M, Katırcı H. Spor Pazarlaması. (3 Baskı). Ankara: Nobel Yayınları, 2015.

86. Çetin C. www.thebrandage.com Kulüp ve Taraftarın Sosyal Medyada Buluşması, 03.10.2017, http://www.thebrandage.com/kulup-ve-taraftarin-sosyal-medyada-bulusmasi-7286 Erişim Tarihi: 03.05.2017.

87. Yıldız SM. Spor ve Fiziksel Etkinlik Hizmetleri Pazarlaması. (2. Baskı). Ankara: Detay Yayıncılık, 2016.

88. Ekmekçi R, Dağlı Ekmekçi YA. Spor Pazarlaması. Pamukkale Journal Of Sport Sciences, Denizli, 2010.

89. Tüfekçi KÖ. Spor Pazarlama Zekası: Marka Kimliği Yaratma Yeteneklerinin Analizi ve Batı Akdeniz Bölgesi Futbol Taban Birliklerinde Bir Uygulama. Isparta: Süleyman Demirel Üniversitesi, Sosyal Bilimler Enstitüsü, İşletme Anabilim Dalı, 2011.

90. Dağlı Ekmekçi AY, İrmiş A. Girişimcilik Ve Spor. International Conferance On Eurasian Economies, St. Petersburg - Russia: Beykent University, 2013; 635-640.

91. Ratten V. Developing A Theory Of Sport-Based Entrepreneurship. Journal Of Management And Organization, 2010; 16: 557-565.

92. Geri S. Research On Entrepreneurial Characteristics Of Students İn School Of Physical Education And Sports, Turkish Journal Of Education, 2013; 2(3): 50-60.

93. Şirin YE, Bilir FP, Öz G. Üniversite Öğrencilerinin Sosyal Girişimcilik Eğilimleri: Beden Eğitimi ve Spor Yüksekokulu Örneği. Gaziantep Üniversitesi Spor Bilimleri Dergisi, 2018; 3(3): 35-47.

94. Gusseinova D. Sosyal Girişimcilik Olgusu ve Bir Örnek Olay İncelemesi. Yüksek Lisans Tezi, İzmir: Dokuz Eylül Üniversitesi, Sosyal Bilimler Enstitüsü, 2015.

95. Ratten V. Sport-Based Entrepreneurship: Towards A New Theory Of Entrepreneurship And Sport Management. International Entrepreneurship Management Journal, 2011; 7: 57-69.

96. Karasar N. Bilimsel Araştırma Yöntemi. Ankara: Nobel Yayın Dağıtım, 1998.

97. Yalçın İncik E, Uzun N. Bireysel Girişimcilik Algı Ölçeği: Geçerlik ve Güvenirlik Çalışması. Mustafa Kemal Üniversitesi Sosyal Bilimler Enstitüsü Dergisi, 2017; 14 (39): 471-485. 
98. Khodadady E, Zabihi R. Social And Cultural Capital: Underlying Factors And Their Relationship With The School Achievement Of Iranian University Student. International Education Studies, 2011; 4(2): 63-71.

99. Saygın M. Kültürel Sermaye, Beşeri Sermaye ve Sosyal Sermayenin Girişimci Kişilik Özelliklerine Etkisi: İç Anadolu Bölgesi Genç Girişimciler Kurulu Örneği. Doktora Tezi, Aksaray: Aksaray Üniversitesi, Sosyal Bilimler Enstitüsü, İşletme Anabilim Dali, 2016.

100. Kurtuluş K. Araştırma Yöntemeleri. İstanbul: Türkmen Kitabevi, 2011.

101. Çokluk Ö, Şekercioğlu G, Büyüköztürk Ş. Sosyal Bilimler İçin Çok Değişkenli İstatistik: Spss ve Lısrel Uygulamaları. Ankara: Pegem Akade$\mathrm{mi}, 2010$.

102. Kalaycı Ş. SPSS Uygulamalı Çok Değişkenli İstatistik Teknikleri. 3. Baskı, Ankara, 2008.

103. Nas K, Temel V. Beden Eğitimi ve Spor Yüksekokulu Öğrencilerinin Girişimcilik Düzeyleri. Atatürk Üniversitesi Beden Eğitimi ve Spor Bilimleri Dergisi, 2018;20(3).

104. Karabulut EO, Karacan Doğan P. Üniversite Öğrencilerinin Girişimcilik Eğilimleri ve Genel Yetkinlik Düzeyleri Üzerine Bir Araştırma; Beden Eğitimi ve Spor Yüksekokulu Örneği. Iğdır Üniversitesi Spor Bilimleri Dergisi, 2019; 2(1): 16-26.

105. Yıldız E. İnönü Üniversitesi Spor Bilimleri Fakültesi Öğrencilerinin Girişimcilik Düzeylerinin İncelenmesi, Yüksek Lisans Tezi, Malatya: İnönü Üniversitesi, Sağlık Bilimleri Enstitüsü, Beden Eğitimi ve Spor Anabilim Dalı, 2020.

106. Özkara AB. Spor Lisesi Öğrencilerinin Girişimcilik Yeterliliklerinin İncelenmesi. Manas Sosyal Araştırmalar Dergisi, 2019; 8 (1): 1304-1312.

107. Tolukan E. Spor Tesisi Yöneticilerinin Girişimcilik Eğilimi ve Liderlik Davranış Özelliklerinin İncelenmesi. Doktora Tezi, Ankara: Gazi Üniversitesi, Eğitim Bilimleri Enstitüsü, Beden Eğitimi ve Spor Öğretmenliği Ana Bilim Dalı, 2014.

108. Öztaş M. Beden Eğitimi ve Spor Yüksek Okulu Spor Yöneticiliği Bölüm Öğrencilerinin Bireycilik ve Toplulukçuluk Kültür Bağlamında Girişimcilik Özelliklerinin Değerlendirilmesi, Yüksek Lisans Tezi, Konya: Selçuk Üniversitesi Sağlık Bilimleri Enstitüsü, Spor Yöneticiliği Anabilim Dalı, 2015.

109. Karataş İ. Beden Eğitimi ve Spor Yüksekokulu Öğrencilerinin Kişilik Özelliklerinin Girişimcilik Eğilimleri Üzerindeki Etkilerinin İncelenmesi: Bartın Üniversitesi Örneği. Yüksek Lisans Tezi, Bartın: Bartın Üniversitesi, Eğitim Bilimleri Enstitüsü, Beden Eğitimi ve Spor Öğretimi Anabilim Dalı, 2018.

110. Kara A. Yükseköğretim Kurumlarında Spor Eğitimi Alan Öğrencilerin Girişimcilik Eğilimi ve Liderlik Özellikleri Üzerine Bir Araştırma. Yük- 
sek Lisans Tezi, İstanbul: İstanbul Üniversitesi, Sağlık Bilimleri Enstitüsü, Spor Yönetim Bilimleri Anabilim Dalı, 2018.

111. Türkmen M, İşbilir U. Entrepreneurship Effect Of Tendency Of Socio-Demographic Characteristics Of University Students. Cbu Journal Of Physical Education And Sport Sciences, 2014; 9(2): 18-28.

112. Demirel DH, Aydoğmuş B, Güneş Ö. Öğretmen Adaylarında Boş Zamanın Anlamı ve Sosyal Girişimcilik İlişkisinin İncelenmesi. 2. Uluslararası Rekreasyon ve Spor Yönetimi Kongresi, 11 - 14 Nisan 2019.

113. Mülhim Z. Beden Eğitimi ve Spor Yüksekokulu Öğrencilerinin Girişimcilik Özellikleri ve Bireysel Yenilikçilik Düzeylerinin İncelenmesi: Bartın Üniversitesi Örneği. Yüksek Lisans Tezi, Bartın: Eğitim Bilimleri Enstitüsü, Beden Eğitimi ve Spor Öğretimi Anabilim Dalı, 2019.

114. Şener F. Beden Eğitimi ve Spor Yüksekokulunda Öğrenim Gören Öğrencilerin Girişimcilik Özellikleri İle İletişim Yeterlilikleri Arasındaki İlişkinin İncelenmesi. Yüksek Lisans, Bartın: Bartın Üniversitesi, Sosyal Bilimler Enstitüsü, Beden Eğitimi ve Spor Anabilim Dalı, 2019.

115. Cengiz R, Serdar E, Donuk B. Analyzing the level of mindfulness and entrepreneurship of the university students. International Journal of Social Sciences and Education Research, 2016; 2(4): 1321-1328.

116. Namlı S, Kaya A. Lisans Öğrencilerinin Girişimcilik Eğilimleri: Tra1 Alt Bölgesi Üniversiteleri Beden Eğitimi ve Spor Öğretmenliği Bölümü Üzerine Bir Araştırma. Etü Sosyal Bilimler Enstitüsü Dergisi, 2019; 9: 155174.

117. Özgüner Z, Özgüner M, Özdemir A. Üniversite Öğrencilerinin Girişimcilik Eğilimlerinin Çeşitli Demografik Değişkenler Bağlamında Değerlendirilmesi. 2nd International Scientific Researches Congress On Humanities And Social Sciences, 2017; 391-403.

118. Şahin Tezcan N, Karakaş A, Kıngır S, Yılmazer A. Sakarya Üniversitesi Öğrencilerinin Girişimcilik Eğilimleri Üzerine Bir Araştırma. Uluslararası Batı Karadeniz Sosyal ve Beşeri Bilimler Dergisi, 2019; 3(1): 50-68.

119. Arıbaş AN. Sağlık Hizmetleri Meslek Yüksekokulu Öğrencilerinin Girişimcilik Düzeylerinin Belirlenmesi. Aksaray Üniversitesi Sosyal Bilimler Enstitüsü Dergisi (Ased), 2019; 3(1).

120. Gemlik N, Kıraç R. Sağlık Yönetimi Öğrencilerinin Girişimcilik Özellikleri Üzerine Bir Araştırma. Kahramanmaraş Sütçü İmam Üniversitesi Dergisi, 2013; 3(1): 163-170.

121. Acar S. Mesleki Eğitim Merkezi Öğrencilerinin Girişimcilik Algılarının İncelenmesi: İstanbul İli Örneği. Yüksek Lisans Tezi, İstanbul: Sosyal Bilimler Enstitüsü, İşletme Anabilim Dalı, Bahçeşehir Üniversitesi, 2019.

122. Özman C. Spor Yöneticiliği Bölümünde Öğrenim Gören Üniversite Öğrencilerinin Girişimcilik Düzeylerinin Belirlenmesi. Yüksek Lisans Tezi, İstanbul: Marmara Üniversitesi, Sağlık Bilimleri Enstitüsü, Beden Eğitimi ve Spor Anabilim Dalı, 2013. 
123. Dilek S, Keskingöz H, Nergiz E, Ekonomi Okuryazarlığının Girişimcilik Niyeti Üzerine Etkisi, Üçüncü Sektör Sosyal Ekonomi Dergisi, 2019; 54(1): 89-107.

124. Kılınç E, Kanayıran B. İşletme Fakültesi Öğrencilerinin Psikolojik Sermaye Düzeylerinin Girişimcilik Eğilimleri Üzerindeki Etkisinin İncelenmesi, 2020; 4(7).

125. Karıman E. Girişimci Üniversite Olma Yolunda Ondokuz Mayıs Üniversitesi Öğrencileri Üzerine Bir Çalışma. Yüksek Lisans Tezi, Samsun: Ondokuz Mayıs Üniversitesi, Sağlık Bilimleri Enstitüsü, Beden Eğitimi ve Spor Anabilim Dalı, 2017.

126. Şeşen H, Basım HN. Demografik Faktörler ve Kişiliğin Girişimcilik Niyetine Etkisi: Spor Bilimleri Alanında Öğrenim Gören Üniversite Öğrencileri Üzerine Bir Araştırma. Ege Akademik Bakış, 2012; 12:21-28.

127. Türkmen M, İşbilir U. Üniversite Öğrencilerinin Girişimcilik Eğilimlerinin Sosyo-Demografik Özellikler Açısından Değerlendirilmesi. Celal Bayar Üniversitesi Beden Eğitimi ve Spor Bilimleri Dergisi, 2015; 9 (2): 18-28.

128. Bahar A, Kocaçal Güler E, Arslan M, İnem AB, Çimen ZS. Hemşirelik Öğrencilerinde Girişimcilik Düzeyi ve Etkileyen Faktörlerin Belirlenmesi. Acu Sağlık Bilimleri Dergisi, 2018.

129. Yanıkkerem E, Karakuş Selçuk A. Hemşirelik Öğrencilerinin Girişimcilik Eğilimi ve Sosyal Medya Bağımlılığını Etkileyen Faktörler. Manisa Celal Bayar Üniversitesi Sağlık Bilimleri Enstitüsü Dergisi, 2019; 6(1): 15-30.

130. Biçer B, Başer EH. Öğretmen Adaylarının Empatik Eğilimlerinin Sosyal Girişimcilik Özelliklerini Yordama Gücü ve Empatik Eğilim İle Sosyal Girişimcilik Özelliklerini Etkileyen Faktörler. Anemon Muş Alparslan Üniversitesi Sosyal Bilimler Dergisi, 2019; 7(5).

131. Öztürk M. Beden Eğitimi ve Spor Öğretmen Adaylarının Girişimcilik Özellikleri İleyansıtıcı Düşünme Düzeyleri Arasındaki İlişkinin İncelenmesi (Sakarya Üniversitesi Örneği). Yüksek Lisans Tezi, Bartın: Bartın Üniversitesi, Eğitim Bilimleri Enstitüsü, Beden Eğitimi ve Spor Öğretmenliği Anabilim Dalı, 2018.

132. Adatepe S. Beden Eğitimi ve Spor Yüksekokulu’nda Okuyan Öğretmen Adaylarının Girişimcilik Özellikleri İle Yansıtıcı Düşünme Düzeylerinin İncelenmesi. Yüksek Lisans Tezi, Bartın: Bartın Üniversitesi, Eğitim Bilimleri Enstitüsü, Beden Eğitimi ve Spor Öğretmenliği Anabilim Dall, 2018.

133. Dağlı Ekmekçi YA, Işık İnan Ö. Gönüllülük Faaliyetinde Bulunan Üniversite Öğrencilerinin Girişimcilik Özellikleri, Üçüncü Sektör Sosyal Ekonomi Dergisi, 2020; 55(1): 246-267.

134. Gencay E, Döven MS. Girişimci Kişilik Özelliklerinin Girişimcilik Niyetine Etkisi: Mersin Üniversitesi'nde Bir Araştırma. Stratejik Yönetim Araştırmaları Dergisi, 2019; 2(1): 89-123. 
135. Bozyokuş H, İyigün E, Ezentaş R. Meslek Yüksekokulu Öğrencilerinin Girişimcilik Uygulamalarının İncelenmesi. Fen, Matematik, Girişimcilik ve Teknoloji Eğitimi Dergisi, 2019; 2(3).

136. Keleş HN, Özkan TK, Doğaner M, Altunoğlu AE. Önlisans Öğrencilerinin Girişimcilik Düzeylerini Belirlemeye Yönelik Bir Araştırma. Uluslararasi İktisadi ve İdari İncelemeler Dergisi, 2012; 9: 107-18.

137. Can M. Veteriner Fakültesi Öğrencilerinin Girişimcilik Potansiyeli ve Eğilimlerinin Analizi: Mustafa Kemal Üniversitesi Örneği. Yyu Veteriner Fakültesi Dergisi 2014; 24:81-6.

138. Kalkan A. Kişisel Tutum, Öznel Norm ve Algılanan Davranış Kontrolünün Girişimcilik Niyeti Üzerindeki Etkisi: Üniversite Öğrencileri Üzerine Bir Uygulama. Süleyman Demirel Üniversitesi Sosyal Bilimler Enstitüsü Dergisi, 2011; 14: 189-206.

139. Koyuncuoğlu D. Kişilik Özelliklerinin Girişimcilik Yetkinliği Üzerinde Etkisi Sürecinde Üniversite Koşullarının Moderator Rolunün İrdelenmesi, Doktora Tezi, Konya: Selçuk Üniversitesi, Sosyal Bilimler Enstitüsü, İşletme Anabilim Dalı, 2019.

140. Akpınar F, Alkış H. Duygusal Zeka ve Girişimcilik Eğilimi: Adıyaman Üniversitesi Öğrencileri Üzerine Bir Araștırma. Adıyaman Üniversitesi Sosyal Bilimler Enstitüsü Dergisi, 2019.

141. Güney A, Çelik E. Sosyal Sermaye İle İşsizlik Kaygısı Arasındaki İlişki: Atatürk Üniversitesi İibf Son Sınıf Öğrencileri Üzerine Bir Uygulama. İstanbul İktisat Dergisi, 2019; 69(1): 103-131.

142. Diken A, Erer B. Sosyal Sermaye ve Örgütsel Bağlllık İlişkisi: Otomotiv Sektöründe Bir Uygulama. 1st International Congress On Applied Sciences: Social Capital - Uubk' 2015; 113.

143. Kaasa A, Parts E. Individual-Level Determinants Of Social Capital In Europe: Differences Between Country Groups. Acta Sociologica, 2008; 51(2): 145-168.

144. Evin E. Kurumsal Sosyal Sermaye Uygulamaları İle Örgütsel Bağlllık İlişkisi Niğde Belediyesi Çalışanları Üzerine Bir Araştırma. Yüksek Lisans Tezi, Konya: Necmettin Erbakan Üniversitesi, Sosyal Bilimler Enstitüsü, İşletme Anabilim Dalı, 2019.

145. Huang L. Social Capital And Student Achievement İn Norwegian Secondary Schools, Learning And Individual Differences: Http://Dx.Doi.Org/10.1016/J.Lindif.2008.11.004), 2008.

146. Akkaş HH, Kaçanoğlu E. Evden Hırsızlık Olaylarının Önlenmesinde Komşuluk İlişkileri ve Sosyal Sermaye: Erzurum İli Örneği. 1st International Congress On Applied Sciences : Social Capital - Uubk'2015.

147. Cansız M, Özbaylanlı B, Çolakoğlu MH. Türkiye'de Kültürel Sermayenin Öğrenim Başarısı Üzerine Etkisi. Journal Of Economy Culture And Society, 2018; 58: 127-152. 
148. Taş MA, Alparslan AM. Kültürel Değerler, Psikolojik Sermaye ve Kariyer Uyum Yeteneği İlişkisine Dair Bir Saha Araştırması. Celal Bayar Üniversitesi Sosyal Bilimler Dergisi, 2020; 18(Özel Sayı): 417-440.

149. Etiz SS. Öğretmenlerin Kültürel Sermaye Yeterlilikleri İle Sosyal Sorumluluk Temelli Liderlik Becerilerinin İncelenmesi, Yüksek Lisans Tezi, Siirt: Siirt Üniversitesi, Sosyal Bilimler Enstitüsü, Eğitim Bilimleri Anabilim Dalı Başkanlığ, 2019.

150. Güleç F. Sınıf Öğretmenlerinin Kültürel Sermaye Yeterlikleri İle Çokkültürlü Eğitime Yönelik Tutumlarının İncelenmesi: Siirt İli Örneklemi. Yüksek Lisans Tezi, Afyonkarahisar: Afyon Kocatepe Üniversitesi, Sosyal Bilimler Enstitüsü, İlköğretim Anabilim Dalı, 2019.

151. Ülkü Pekkan N. Sosyal Sermaye ve Öz-Yeterliliğin İşe Yabancılaşma Üzerine Etkisi: Sağlık Sektöründe Bir Araştırma. Doktora Tezi, Osmaniye: Osmaniye Korkut Ata Üniversitesi, Sosyal Bilimler Enstitüsü, İşletme Ana Bilim Dalı, 2017.

152. Bayhan İ. Liderlik Davranışının Duygusal Emek ve Yenilikçi İklim Üzerindeki Etkisinde Sosyal Sermaye İle Entelektüel Sermayenin Aracilık Rolü: Otel İşletmelerinde Bir Araştırma. Doktora Tezi, İstanbul: İstanbul Üniversitesi, Sosyal Bilimler Enstitüsü, Turizm İşletmeciliği Anabilim Dalı, İstanbul, 2018.

153. Şanin MM. Motivasyonun, Sosyal Sermaye ve İş Tatmini Arasındaki Aracllık Etkisinin Araştırılması: Batman Üniversitesinde Bir Uygulama. Yüksek Lisans Tezi, Batman: Batman Üniversitesi, Sosyal Bilimler Enstitüsü, İşletme Anabilim Dalı, 2019.

154. Bucak A. Öğretmenlerin Kültürel Sermaye ve Yetkinlik Düzeyleri Arasındaki İlişkinin İncelenmesi. Yüksek Lisans Tezi, Siirt: Siirt Üniversitesi, Sosyal Bilimler Enstitüsü, Eğitim Bilimleri Anabilim Dalı, 2019.

155. Erdoğan S. Okul Yöneticilerinin Kültürel Sermaye Düzeyleri İle Okul Kültürü Arasındaki İlişki. Yüksek Lisans Tezi, Ankara: Ankara Üniversitesi, Eğitim Bilimleri Enstitüsü, Eğitim Yönetimi Ve Politikası Anabilim Dalı, 2019.

156. Yıldırım E. Sosyal Sermaye ve Bireysel Motivasyon Faktörlerinin Bilgi Paylaşma Niyeti Üzerine Etkisi. Yüksek Lisans Tezi, İstanbul: Marmara Üniversitesi, Sosyal Bilimler Enstitüsü, İşletme Anabilim Dalı, 2019.

157. Turgut E. Sosyal Sermaye ve Bilgi Paylaşımı Davranışının Yenilikçilik İklimine Etkisi. Doktora Tezi, Ankara: Gazi Üniversitesi Sosyal Bilimler Enstitüsü, 2013.

158. Celep O. Dönüşümsel ve Etkileşimsel Liderlik Tarzlarının Sosyal Sermaye ve Lider-Üye Etkileşimine Etkisi: Otel İşletmelerinde Bir Araştırma. Yüksek Lisans Tezi, Çanakkale: Çanakkale Onsekiz Mart Üniversitesi, Sosyal Bilimler Enstitüsü, İşletme Anabilim Dalı, 2019.

159. Gökalp S. Okul Yöneticilerinin Kültürel Sermaye Yeterliklerinin ve Kültürel Liderlik Rollerini Yerine Getirme Düzeylerinin İncelenmesi. Doktora 
Tezi, Gaziantep: Gaziantep Üniversitesi, Eğitim Bilimleri Enstitüsü, Eğitim Bilimleri Ana Bilim Dalı, 2018.

160. Sarı O. Devlet Okullarında ve Özel Okullarda Görev Yapan Öğretmenlerin Sosyal Sermaye Kavramına İlişkin Algıları. Yüksek Lisans Tezi, İstanbul: İstanbul Üniversitesi, Cerrahpaşa Lisansüstü Eğitim Enstitüsü, Eğitim Bilimleri Anabilim Dalı, 2019.

161. Ardahan F, Ezici MN. İlköğretim Sekizinci Sınıf Öğrencilerinin Sosyal Sermaye Profili, Sosyal Sermaye ve Başarı Durumunun Çeşitli Demografik Değişkenlere Göre Değerlendirilmesi: Antalya Örneği. Sakarya University Journal Of Education, 2015; 5(1): 16-36.

162. Ersözlü A. Sosyal Sermayenin Ortaöğretim Kurumlarında Görev Yapan Öğretmenlerin İş Doyumuna Etkisi (Tokat İli Örneği). Yüksek Lisans Tezi, Elazığ: Fırat Üniversitesi, Sosyal Bilimler Enstitüsü, 2008.

163. Direk A. Eğitim Örgütlerinde Sosyal Sermaye ve Şiddet Eğilimi Düzeyi. Doktora Tezi, Sakarya: Sakarya Üniversitesi, Sosyal Bilimler Enstitüsü, 2019.

164. Gölpek Karababa A. Üniversite Öğrencilerinin Sosyal Sermaye Düzeyleri Demografik Faktörlere Göre Değişiyor Mu? Yükseköğretim ve Bilim Dergisi/Journal Of Higher Education And Science, 2019; 9(3): 413-429.

165. Tatar L. Mesleki Eğilimin Toplumsal Hiyerarşisi: Kültürel Sermaye ve Simgesel Şiddet Ekseninde Mesleki Tasnif. Yüksek Lisans Tezi, Balıkesir: Balıkesir Üniversitesi, Sosyal Bilimler Enstitüsü, Sosyoloji Anabilim Dalı, 2018.

166. Oral I. Mcgivney EJ. Türkiye Eğitim Sisteminde Eşitlik ve Akademik Başarı Araştırma Raporu ve Analiz. 2014, Http://Www.Egitimreformugirisimi.Org/Turkiye-Egitim-Sisteminde-Esitlik-Ve-Akademik-Basari/ (Erişim Tarihi: 21.02.2019).

167. Tösten R, Avcı YE, Şahin ÇÇ. Öğretmenlerin Kültürel Sermaye Yeterliklerinin İncelenmesi: Meslek Liseleri Örneği. Atatürk Üniversitesi Kazım Karabekir Eğitim Fakültesi Dergisi, 2017; 35: 130 - 143.

168. Kraaykamp G, Van Eijck K. The İntergenerational Reproduction Of Cultural Capital: A Threefold Perspective. Social Forces, 2010; 89(1): 209231.

169. Uçak Azboy Z. Üstün Zekalı/ Yetenekli Çocuklarda Psikolojik Sağlamlık ve Sosyal Sermaye İlişkisi. Yüksek Lisans Tezi,Mersin: Çağ Üniversitesi, Sosyal Bilimler Enstitüsü, Psikoloji Ana Bilim Dalı, 2020.

170. Güngör G. İlköğretim Okullarının Öğretmen Görüşlerine Göre Sosyal Sermaye Düzeyleri ve Dezavantajlılıkları İle İlgili Değişkenler Arasındaki İlişki (Mersin İli Mezitli İlçesi Örneği). Yüksek Lisans Tezi, Mersin: Mersin Üniversitesi, Eğitim Bilimleri Enstitüsü, 2011.

171. Koçtürk M, Salkım Er A. Sosyal Sermaye Bileşenlerinin Kırsal Alan Yaşam Memnuniyeti Üzerine Etkisi: Manisa Örneği 12. Tarım Ekonomisi Kongresi, 2016. 
172. Tekin M, Sayın AA, Samancı TH. Deneyimsel Pazarlamada Sosyal Sermaye: Beyaz Eşya Tüketimi Davranışları Araştırması. 1st International Congress On Applied Sciences : Social Capital - Uubk' 2015; 884.

173. Aktaş G. Farklı Sosyo-Ekonomik ve Kültürel Özelliklere Sahip Ailelerde Kız Çocuklarına İlişkin Aile İçi Kültürel Tanımlamalar. Doktora Tezi, Ankara: Hacettepe Üniversitesi, Sosyal Bilimler Enstitüsü, Sosyoloji Anabilim Dalı, 2011.

174. Andersen IG, Jæger MM. Cultural Capital İn Context: Heterogeneous Returns To Cultural Capital Across Schooling Environments. Social Science Research, 2015; 50: 177-188.

175. Giderler C, Çetinoğlu T, Bakar Ö. Çalışanların Sosyal Sermaye Düzeylerini Belirlemeye Yönelik Bir Araştırma: Uygulamalı Bilimler Yüksek Okulları Örneği. 1st International Congress On Applied Sciences : Social Capital - Uubk' 2015; 815.

176. Yahyagil MY. Values, Feelings, Job Satisfaction And Well-Being: The Turkish Case. Management Decision, 2015; 53(10): 2268-2286.

177. Şahin C, Akan D, Başar M. Okullardaki Sosyal ve Entelektüel Sermaye İlişkilerinin ve Düzeyinin Öğretmen Görüşlerine Göre İncelenmesi. Uşak Üniversitesi Sosyal Bilimler Dergisi, 2014; 7 (2): 300-320.

178. Oo1 CA, Hooy CW, Som APM. Diversity İn Human And Social Capital: Empirical Evidence From Asian Tourism Firms İn Corporate Board Composition. Tourism Management, 2015; 48: 139-153.

179. Akyürek Mİ. Okullarda Sosyal Sermaye ve Örgüt Sağlığı İlişkisi. Doktora Tezi, Ankara: Gazi Üniversitesi, Eğitim Bilimleri Enstitüsü, Eğitim Bilimleri Ana Bilim Dalı, 2019.

180. Püsküllüoğlu EI. Öğretmen Görüşlerine Göre Lise Müdürlerinin Sosyal Sermaye Düzeyleri İle Öğretmenlerin Tükenmişlik Düzeyleri Arasındaki İlişki: Muğla İli Örneği. Yüksek Lisans Tezi, Muğla: Muğla Sitkı Koçman Üniversitesi, 2015.

181. Tösten R, Avcı YE, Şahin ÇÇ. Öğretmenlerin Kültürel Sermaye Yeterliklerinin İncelenmesi: Meslek Liseleri Örneği. Atatürk Üniversitesi Kazım Karabekir Eğitim Fakültesi Dergisi, 2017; 35: 130 - 143.

182. Dehcheshmeh FN. The Role Of Social Capital In Intrapreneurship Of Health Department Staff, Iajps, 2017; 4 (12): 4739-4744.

183. Işık M, Çiçek B. Planlı Davranış Teorisi Perspektifinden Girişimcilik Niyeti Üzerinde Sosyal Sermaye Öz Yeterlilik ve Öz Saygının Rolü, Turkish Studies - Economy, 2020:15(1); 185-206.

184. Bal Taştan S, Torun A. Kültürel Değerlerin, Yerleşiklik Derecesinin, Güven Algısının ve Çevresel Belirsizliğin Örgütlerde Sosyal Sermaye Yapısı İle İlişkilerinin İncelenmesi: Küçük ve Orta Ölçekli Firmalar Üzerinde Yapılan Bir Araştırma. Akademik Bakış Dergisi, 2015. 